\title{
MECHANICAL DRILL FOR DEEP CORING IN TEMPERATE ICE
}

\author{
By Bragi Árnason, Helgi Björnsson and Páll Theodórsson \\ (Science Institute, University of Iceland, Reykjavík, Iceland)
}

\begin{abstract}
A rotary drill for deep coring in temperate ice has been constructed and tested. The total length of the drill is $6 \mathrm{~m}$ and its weight is $100 \mathrm{~kg}$. A steel armoured cable carries power to the $2 \mathrm{~h}$.p. electric motor of the drill. The diameter of the core is $90 \mathrm{~mm}$ and the maximum length of core is $2 \mathrm{~m}$. An antifreeze mixture at the bottom of the hole was necessary to prevent refreezing of ice chips on the cutting bits.

A $415 \mathrm{~m}$ deep hole was drilled during the summer of 1972 into the temperate accumulation area of Vatnajökull. Core recovery was $99 \%$. Because of a fault in the cable the bottom was not reached.

RÉsumÉ. Foreuse mécanique pour sondage profond en glace tempérée. On a construit et expérimenté une foreuse rotative pour sondage profond en glace tempérée. La longueur totale de la foreuse est de $6 \mathrm{~m}$ et son poids de $100 \mathrm{~kg}$. Un câble armé d'acier alimente le moteur électrique de $2 \mathrm{CV}$ de puissance, de la foreuse. Le diamètre du forage est de $90 \mathrm{~mm}$ et la plus grande longueur de carotte de $2 \mathrm{~m}$. Un mélange antigel au fond du trou est nécessaire pour prévenir le regel des copeaux de glace sur les taillants.

Un forage de $415 \mathrm{~m}$ de profondeur a été creusé pendant l'été 1972 dans la zone tempérée d'accumulation du Vatnajökull. On a récupéré $99 \%$ de la longueur de carottage. Une défaillance du câble a empêché d'atteindre le fond.

Zusammenfassung. Ein mechanischer Bohrer für tiefe Kern-Bohrungen in temperiertem Eis. Zur Gewinnung tiefer Kerne in temperiertem Eis wurde ein Drehbohrer konstruiert und erprobt. Die Gesamtlänge des Bohrers beträgt $6 \mathrm{~m}$, sein Gewicht too kg. Ein stahlarmiertes Kabel liefert den Strom an den 2-PSElektromotor des Bohrers. Der Kern hat einen Durchmesser von $90 \mathrm{~mm}$ und eine maximale Länge von $2 \mathrm{~m}$. Um das Wiederanfrieren von Eisstücken an die Schneidezähne zu vermeiden, musste ein Gefrierschutzmittel auf den Grund des Bohrloches gebracht werden.

Im temperierten Akkumulationsgebiet des Vatnajökull wurde während des Sommers I972 ein $415 \mathrm{~m}$ tiefes Loch gebohrt, wobei $99 \%$ des Bohrkernes geborgen werden konnten. Infolge eines Fehlers im Kabel wurde der Untergrund nicht erreicht.
\end{abstract}

\section{INTRODUCTION}

Core drilling is important for various glaciological studies. Extensive deep drilling has been carried out in polar glaciers and this technique is well developed (Ueda and Garfield, 1969; Langway, 1970; Langway and Hansen, 1970). However, little has been done in the field of drilling for deep cores in temperate glaciers.

Two types of drill have been used: mechanical and thermal drills. Of these, the thermal drill is much simpler and this type was therefore tried in the initial phase of our study.

Two attempts were made to drill deep holes into Vatnajökull glacier with a thermal drill, and a depth of $108 \mathrm{~m}$ was reached during the second attempt in the summer of 1969; (Árnason, 1969, r970; Theodórsson, r969). After solid ice had been reached (below 30 m), the core was partially melted and below $102 \mathrm{~m}$ no core was recovered. This difficulty was most probably caused by a thick ash layer. Because of such ash layers, thermal drills are unsuitable for deep drilling in Icelandic glaciers.

The mechanical drill developed at the U.S. Army Cold Regions Research and Engineering Laboratory for polar glaciers is rather complex. A simpler drill was therefore designed and constructed for drilling in temperate glaciers and it was intended to be used in a hole filled with water.

\section{DESGRIPTION OF THE MEGHANIGAL DRILL}

Figure I shows a cross-section of the drill that was constructed and used. The function of the drill is briefly as follows. A $2.0 \mathrm{~m}$ long core barrel rotates inside a stationary cover tube. Two cutting bits on the lower end of the core barrel cut a $15 \mathrm{~mm}$ wide groove into the bottom of the hole. The ice chips are carried up into the storage compartment above the core barrel by a helical rib on the barrel. After each run the storage compartment is emptied. 


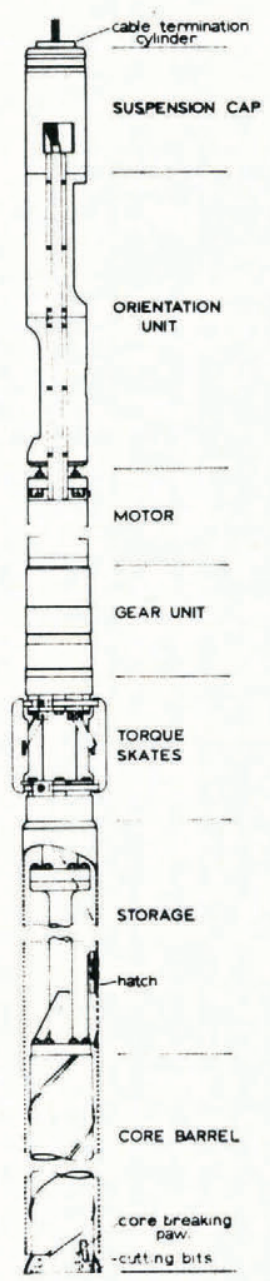

Fig. 1. Cross-section of the mechanical drill.

The total length of the drill is $6.0 \mathrm{~m}$. One-third of this is occupied by the motor, gearbox and torque shoes, one-third by the storage compartment and the lowest third by the core barrel. The two lower sections are surrounded by the cover tube.

The drill will now be described in detail starting from the top. The steel armour of the cable is fastened to the cable-termination cylinder with an alloy of low melting point as described by Ueda and Garfield (1969). A rim on the lower end of this cylinder carries a stiff helical spring. The top part of the drill, the suspension cap, rests on the upper end of this spring and compresses it (Fig. 2a). The purpose of this arrangement is to sense the decrease in the load carried by the spring. When the cutting bits touch the bottom of the hole, they will carry a part of the weight of the drill and this will partially release the compression of the spring. When about $70 \%$ of the weight of the drill is resting on the bottom, a microswitch in the suspension cap is activated, short-circuiting one of the signal leads to ground (armour of cable). Pulling the drill upwards with a force of about $30 \%$ of its weight gives the necessary restoring force against tilting, and this helps to keep the hole vertical. 


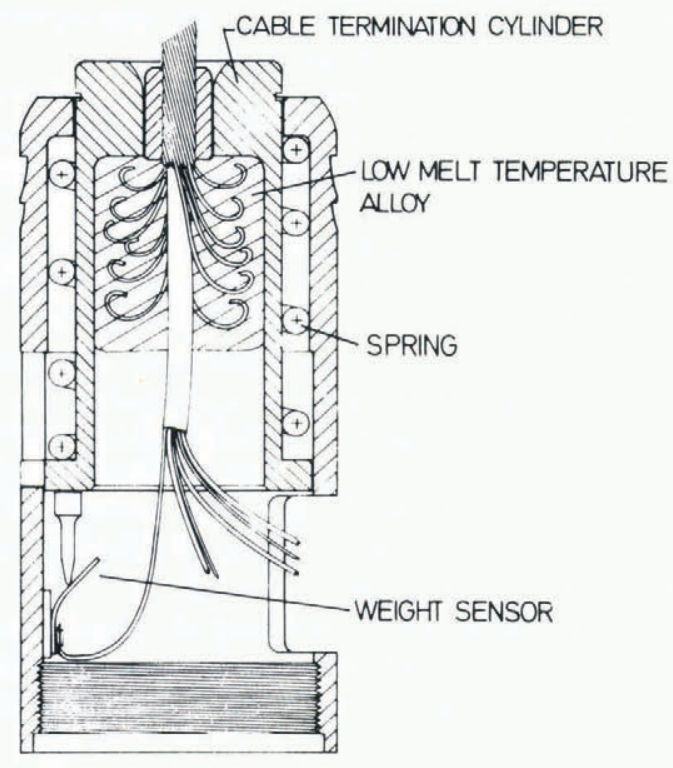

(a)
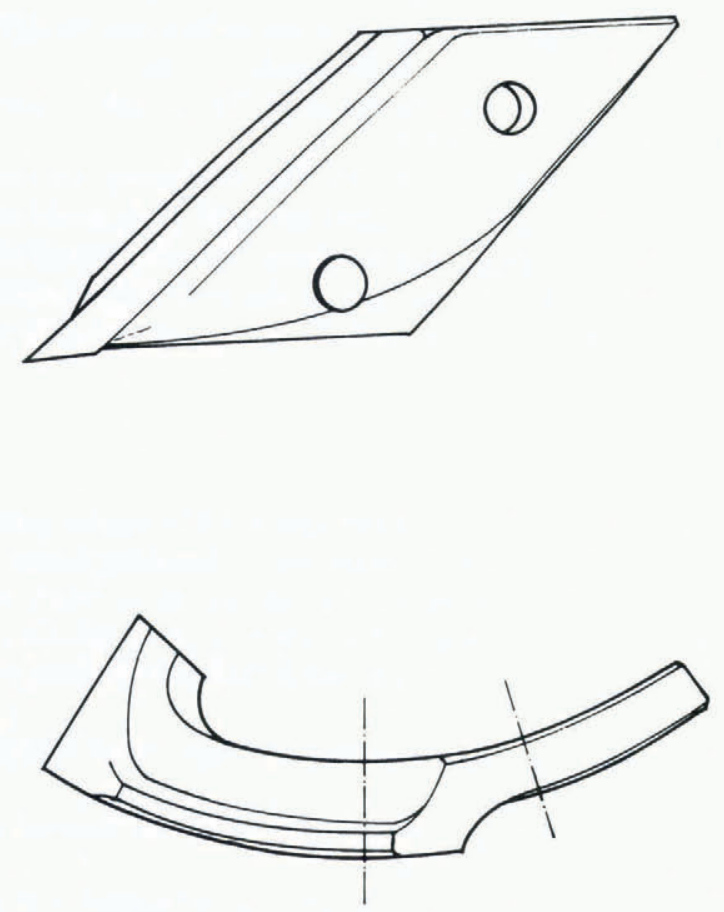

(c)
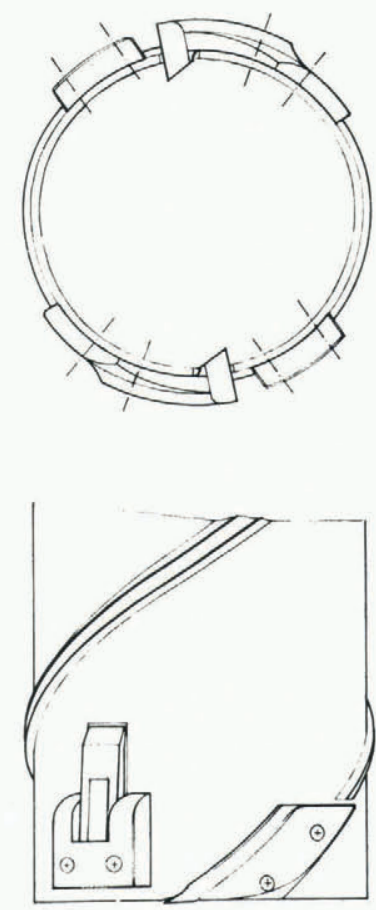

(b)
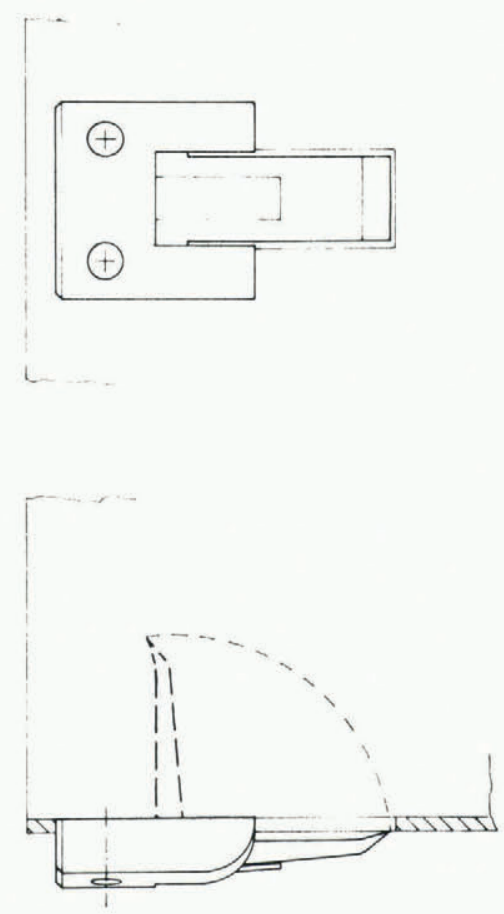

(d)

Fig. 2.

a. The suspension cap and cable-lermination cylinder.

b. The lowest part of the core barrel, side view and end view.

c. Cutting bits.

d. Core-breaking pawl. 
The microswitch gave some trouble and therefore it was replaced later with a direct contact between a pin and an insulated spring, and this measured the d.c. resistance in the water-filled gap with an ohmmeter. In addition to being simpler, this arrangement also showed when the pin was closing in on the spring by a fall in the resistance.

The suspension cap is screwed to the upper end of the orientation unit. A commercial single-shot inclinometer which also gives the bearing fits into this unit. Because of failures of the signal leads in the original cable and because of time shortage after the second cable had been acquired, this unit was never used.

The electric motor is three phase $380 \mathrm{~V}$ a.c., 2 h.p., and the speed of rotation is 2800 r.p.m. This motor is made for a submersible pump. Usually it is filled with water but in order to avoid damage due to accidental freezing the motor was filled with thin oil. Speed is reduced by a planetary gear train to 150 r.p.m. The gear was taken from the starter of a Douglas DC-3 aircraft, but the high-speed stage of the gear had been removed.

Below the motor there are three torque shoes that are pressed against the ice wall by steel springs to prevent the rotation of all parts but the core barrel. Some difficulties were experienced during drilling in firn because the shoes did not hold firmly enough. This was possibly caused by the unsatisfactory shape of the shoes. After some modification of them, no further trouble was experienced, but by then drilling was in solid ice.

In order to make room for the ice chips, a $2 \mathrm{~m}$ long axle lies between the gear and the core barrel, and the storage compartment is the annular space between the axle and the cover tube. At the lower end of the cover tube there is a hatch for emptying the storage compartment after each run.

The core barrel is $2.0 \mathrm{~m}$ long and the space between the barrel and cover tube is $6 \mathrm{~mm}$. There is a double helical rib on the core barrel with a pitch of $20 \mathrm{~cm}$ at the lower end of the barrel increasing to $26 \mathrm{~cm}$ at the top. The increasing pitch is necessary to prevent clogging of the narrow space between the core barrel and the cover tube by the ice chips.

Two cutting bits are screwed to the lower end of the core barrel as well as a pair of pawls for breaking and holding the ice core when the drill is pulled up.

There was a fear that the drill might become stuck in the hole because of closure, ice chips clogging it up, or for some other reason. In order to be better able to meet such problems, three $\mathrm{I}$ kW electrical heaters could be put into the storage compartment. It was hoped that the heat together with circulation of water caused by the rotation of the core barrel would help in loosening the drill if it became stuck. These fears proved to be unfounded and the heaters were only given a short trial.

\section{OTHER EQUIPMENT}

The cable was designed to deliver power to both the drill motor and a $3 \mathrm{~kW}$ heater which could be put into the drill. The starting current of the motor was the main deciding factor for the power conductors of the cable. The cable had three signal conductors $\left(0.75 \mathrm{~mm}^{2}\right)$ and three power conductors $\left(4 \mathrm{~mm}^{2}\right)$, an outer armour of steel and finally a plastic protective layer. The diameter of the cable was $22 \mathrm{~mm}$, its weight was $0.75 \mathrm{~kg} / \mathrm{m}$ and it had a total length of $720 \mathrm{~m}$.

The winch was driven by a $5 \mathrm{~kW}$ electric motor through a belt drive. The mean speed of hoisting and lowering the drill was $25 \mathrm{~m} / \mathrm{min}$.

Electricity was delivered by a $15 \mathrm{~kW}$ gasoline power plant, but not all of this power was needed. This plant was under a separate shelter outside the pit.

In order to secure good working conditions, the drilling equipment was arranged in a pit, $7 \mathrm{~m}$ long, $2.7 \mathrm{~m}$ wide and $4.2 \mathrm{~m}$ deep. The pit was covered with a roof made of polyethylene foil fastened to a wood frame. Figure 3 shows the installation of the drilling equipment in the pit. 


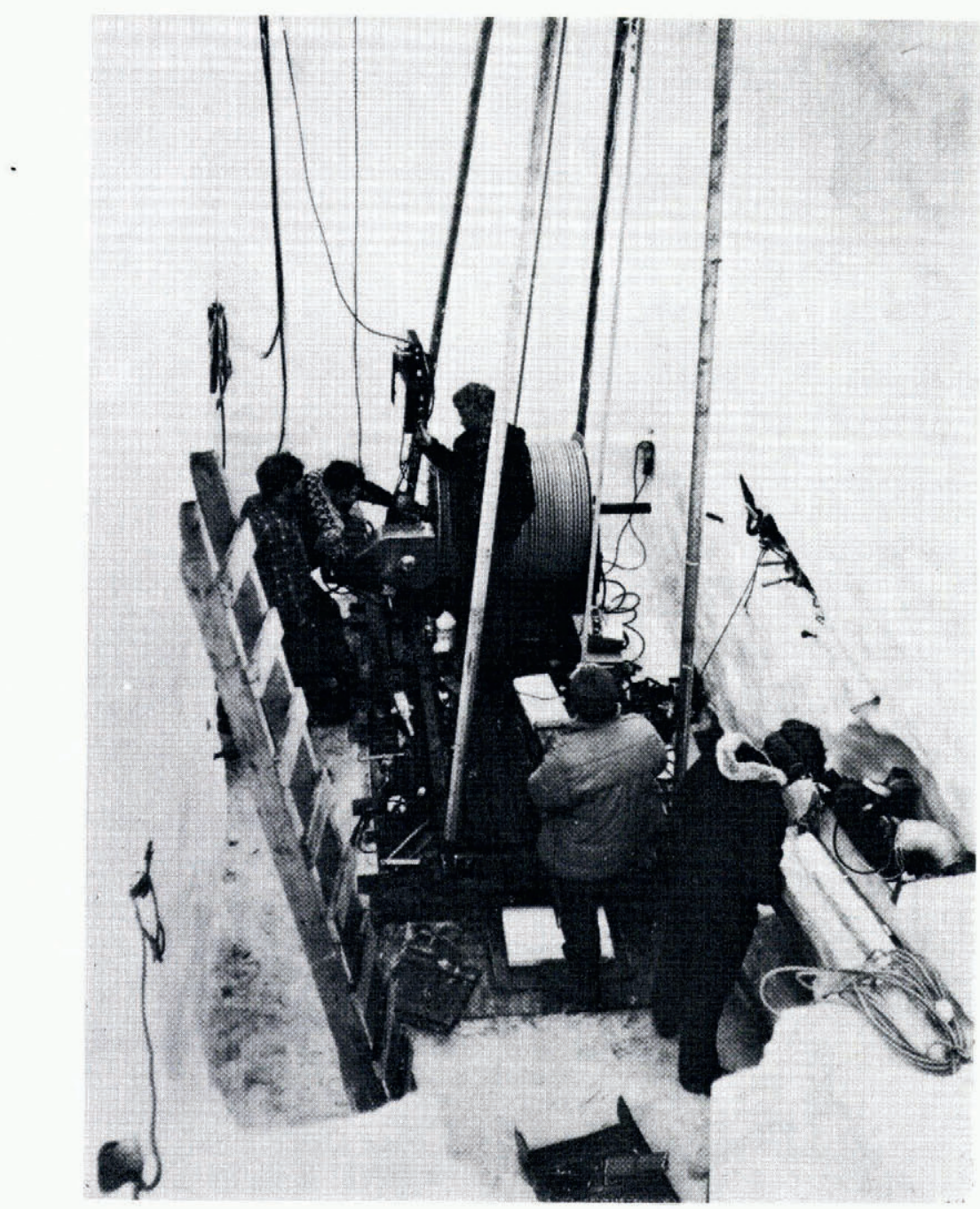

Fig. 3. View into the drilling pit during operation.

\section{DRILLING WORK}

The new drill was used in the summer of 1972 to drill a $4{ }^{1} 5 \mathrm{~m}$ deep hole into Bardarbunga on Vatnajökull glacier, Iceland. On the whole the drilling was successful although there were many difficulties. The expedition lasted so weeks but during five of these the drill was inoperative.

The drilling was done in two shifts with 2 or 3 men on each shift. When the various difficulties had been overcome and sufficient experience gained with the equipment, the following factors decided the drilling speed. The speed of hoisting and lowering the drill was 20-30 $\mathrm{m} / \mathrm{min}$. The drilling and breaking off the core took 5-7 min. Finally, the surface work with the drill after each run took about ${ }_{5} \mathrm{~min}$.

The cable for the drill was the cause of the most serious difficulties. The drill would often sit quite tight in the hole at the end of the drilling, probably because of the clogging and 
partial freezing together of ice chips between the cover tube and wall of the hole at the bottom, and possibly also because of the difficulty of breaking off the ice core. About half of the maximum allowable tension of the cable was applied in loosening the drill, but often there was a wait of several minutes until the drill became loose. On a few occasions it was necessary to wait up to an hour, and in a single case for several hours. In spite of the limited pulling force, the conductors in the cable frequently broke, especially the signal leads. This breakage probably occurred because the steel armour was not woven tightly enough and an inelastic creep occurred in the armour, resulting in too great a tension in the leads of the cable.

The cable had to be shortened four times because of breakage in the conductors, and the faulty section was discarded. Finally, a break in one of the power leads stopped the drilling when a depth of $298 \mathrm{~m}$ had been reached. Fortunately it was possible to borrow a new cable from the U.S. Army Cold Regions Research and Engineering Laboratory in Hanover, New Hampshire. The new cable was, however, only $425 \mathrm{~m}$ long. With this cable I $7 \mathrm{~m}$ were drilled in 8 days, stopping at a depth of $4{ }^{1} 5 \mathrm{~m}$, but the bottom of the glacier was not reached. A thickness of $400-500 \mathrm{~m}$ had been estimated.

The drill was designed to take a $2 \mathrm{~m}$ long core on each run, but only once was a full-length core obtained. The drill would usually cut about $30-40 \mathrm{~cm}$ easily but after that the drilling speed fell seriously and it finally came to a halt. The mean length of the cores was $70-80 \mathrm{~cm}$. Various types of cutters were tried and some other modifications were made on the drill, but this did little to increase the drilling speed. Pulling the drill up a little and then releasing it quickly helped considerably but this became less effective as the depth of the hole increased. At the same time, ice chips frozen around the bits on the core barrel gave an indication of the cause of the slow drilling speed.

During drilling, the edges of the cutting bits are pressed against the ice, both as a result of the weight of the drill and the forced rotation of the drill barrel. This pressure will decrease the melting point of the ice at the point of contact and melt some ice. Heat is therefore conducted from the cutting bits and the bottom end of the core barrel. The ice chips and water come into contact with the steel at a temperature below zero and will therefore freeze on to the cutting bits, finally covering the edges and the cutting will stop.

The mean force on the two cutting tools can be taken to be about $500 \mathrm{~N}$ and the area to which this force is applied can be conservatively estimated as $0.5 \times 10^{-4} \mathrm{~m}^{2}$, generating a pressure of 100 bar at the area of contact This would lower the melting point by $0.7^{\circ} \mathrm{C}$, which seems to give a plausible explanation of the low drilling speed.

This difficulty was overcome by introducing an antifreeze mixture to the bottom of the water-filled hole. A closed polyethylene bag containing about $\mathrm{i} 8 \mathrm{oml}$ of isopropyl alcohol was tied to the inside of the lower end of the core barrel. The bag was thus lowered to the bottom of the hole with the drill and without being damaged. When the drill starts and the ice core penetrates into the core barrel the bag bursts and the vigorous stirring of the rotating core barrel mixes the alcohol with the water, lowering the freezing point. This technique brought quick and positive results. After this it was possible to drill $100-140 \mathrm{~cm}$ in about $6 \mathrm{~min}$., but previously it would take $30-50 \mathrm{~min}$. to drill $60-80 \mathrm{~cm}$. After drilling $120-160 \mathrm{~cm}$, the drilling speed would fall seriously, probably because by then the alcohol mixture had been diluted so much that freezing on the bits would start. The use of an antifreeze mixture can have an undesirable effect on the core for some studies. A future version might have a heater at the lower end of the core barrel to prevent freezing of the ice chips.

After this technique had been introduced, it could be said that all difficulties in the drilling work had been overcome.

No serious closure of the hole was detected despite the long drilling time. At a depth of $34 \mathrm{~m}$ below the surface of the glacier the water table was drilled through and after that the water level stayed the same despite increasing the depth of the hole. The drill had no 
difficulty in going through the numerous volcanic ash layers, the thickest of which was $9 \mathrm{~cm}$.

The quality of the ice cores was very good. Usually the core was in one piece, and recovery was better than $99 \%$. The diameter of the core was $90 \mathrm{~mm}$ and that of the hole $120 \mathrm{~mm}$.

\section{Congluding REMARKS}

The mechanical drill described in this paper has proved to be suitable for deep core drilling in a temperate glacier. For future work the drill would be modified. Because of the refreezing of the ice chips, the full length of the $2.0 \mathrm{~m}$ long core barrel can seldom be used, even when using an antifreeze mixture. The full length might, however, be used if the antifreeze mixture is pumped continuously to the bottom of the hole.

Except when drilling holes deeper than about $600 \mathrm{~m}$, it would probably be better to shorten the core barrel to about $1.2 \mathrm{~m}$ and the ice-chip storage compartment correspondingly. This would shorten the drill considerably and make it lighter. The total weight of the winch and the power plant could also be reduced considerably, and thus the total weight of the drilling equipment. Furthermore, this could also make the drill quite useful for drilling shallow holes into glaciers.

\section{Acknowledgements}

The authors wish to express their appreciation to Mr Karl Benjamínsson for excellent work and very valuable suggestions in designing and constructing the drill. We also wish to thank the Public Roads Administration of Iceland who assisted with transportation to the glacier. A great part of the drilling work was carried out by members of the Icelandic Glaciological Society who participated in the expedition as volunteers. This work was made possible by financial support from the International Atomic Energy Agency.

MS. received 9 March 1973 and in revised form 9 fuly 1973

\section{REFERENCES}

Árnason, B. 1969. The exchange of hydrogen isotopes between ice and water in temperate glaciers. Earth and Planetary Science Letters, Vol. 6, No. 6, p. 423-30.

Árnason, B. 1970. Exchange of deuterium between ice and water in glaciological studies in Iceland. (In Isotope hydrology 1970. Proceedings of a symposium on use of isotopes in hydrology held by the International Atomic Energy Agency in co-operation with the United Nations Educational, Scientific and Cultural Organization in Vienna, 9-13 March 1970. Vienna, International Atomic Energy Agency, p. 59-7 I.)

Langway, C. C., jr. 1970. Stratigraphic analysis of a deep ice core from Greenland. Geological Society of America. Special Paper 125.

Langway, C. C., jr., and Hansen, B. L. I970. Drilling through the ice cap. Probing climate for a thousand centuries. Bulletin of the Atomic Scientists, Vol. 26, No. I, p. 62-66.

Theodórsson, P. 1969. Prívetni í grunnvatni og jöklum á Íslandi. Jökull, Ár 18, 1968, p. 350-58.

Ueda, H. T., and Garfield, D. E. 1969. Core drilling through the Antarctic ice sheet. U.S. Cold Regions Research and Engineering Laboratory. Technical Report 231. 